\title{
Title: A systematic review of the effects of psychosocial interventions on social functioning for middle-aged and older-aged adults with severe mental illness
}

Running title: Psychosocial interventions for older adults with severe mental illness

Key Words: Severe Mental Illness; Psychosocial intervention; Social functioning; Schizophrenia

Authors: Dr Emily L. Smart ${ }^{1}$, Dr Laura Brown ${ }^{1}$, Dr Jasper Palmier-Claus ${ }^{2}$, Ms Jessica Raphael $^{1}$, Professor Katherine Berry ${ }^{1 *}$

${ }^{1}$ Division of Psychology and Mental Health, Faculty of Biology, Medicine and Health, University of Manchester, Manchester Academic Health Science Centre, Manchester, UK ${ }^{2}$ Division of Health Research, Faculty of Health and Medicine, Lancaster University, Lancaster, UK

*Correspondence to: Dr Katherine Berry, Division of Psychology and Mental Health, School of Health Sciences, Faculty of Biology, Medicine and Health, University of Manchester, Manchester Academic Health Science Centre, $2^{\text {nd }}$ Floor, Zochonis Building, Brunswick Street, Manchester, M13 9PL, UK. Katherine.Berry@manchester.ac.uk 


\begin{abstract}
:
Objectives: The number of older adults with severe mental health problems such as schizophrenia is likely to double in the next 20 years. The needs of this patient group change across the life course, but difficulties with social functioning persist into older age. Poorer social functioning is associated with poorer outcomes and has been identified as a priority for intervention by patients themselves. This paper systematically reviews studies examining the effectiveness of psychosocial interventions on social functioning for people with severe mental health problems in later life.
\end{abstract}

Methods: A systematic review of peer-reviewed journal articles was conducted and databases were searched from inception to December 2017. The review was limited to psychosocial interventions, for mid to older aged adults ( $\geq 40$ years of age) with severe mental illness (SMI) that included a validated measure of social functioning.

Results: Fifteen studies (seventeen papers) met inclusion criteria. There was evidence to support skills training interventions that primarily focused on social skills training or integrated mental and physical health interventions. There was not sufficient evidence to recommend any other interventions.

Conclusions: The results highlight the limited nature of interventions designed specifically for older people with severe mental health problems that target social functioning and the need for more robust, large-scale studies in the area. Current evidence suggests that CBT can be effective in targeting social functioning in younger age groups, but, as yet, there is insufficient evidence to recommend this intervention for an older population. 


\section{Highlights}

- The needs of people with severe mental health problems are likely to change across the life course, but difficulties with social functioning persist into older age.

- There is some evidence to support the use of skills training interventions that primarily focus on social skills training or integrated mental and physical health interventions.

- There are few well controlled studies of psychosocial interventions specifically for older people with severe mental health problems.

\section{Introduction}

According to the World Health Organisation (WHO) schizophrenia is one of the top contributors to the world burden of disease ${ }^{1}$. With an ageing population, there is a growing number of older people with severe mental illnesses, such as schizophrenia, which poses a significant challenge to health and social care current services ${ }^{2}$. Antipsychotics are effective in reducing the psychotic symptoms associated with schizophrenia, such as delusions and hallucinations ${ }^{3}$, but have more limited effect on so-called negative symptoms ${ }^{4}$. Negative symptoms can be conceptualised as the absence or reduction in normal affective, behavioural and social functioning, and are one of the biggest predictors of quality of life for people with schizophrenia and social recovery ${ }^{5}$. Whilst psychotic symptoms generally recede in older age, negative symptoms persist ${ }^{6}$ and older people are more likely to report problems with social functioning compared to both younger people with the condition and same age-peers without the diagnosis, including those with other types of mental health problems ${ }^{7}$.

Research demonstrates the effectiveness of psychosocial interventions for improving social functioning in schizophrenia ${ }^{8,9}$. For example, one meta-analysis reported that Cognitive Behaviour Therapy (CBT) had a mean weighted effect size of 0.38 on functioning 9 . However, across the literature as a whole, the majority of randomised control trials of psychological treatments for severe mental illness aim to address psychotic symptoms and do not specifically target social functioning ${ }^{8,9}$. The vast majority of research has also been 
conducted with working-aged adults from 18-65 years, with comparatively limited attention focusing on psychological treatments for older adults ${ }^{8,9}$. We cannot assume that interventions that are effective for younger adults work equally as well for older people, as older people often have unique needs requiring specifically tailored and validated interventions ${ }^{10}$. For example, interventions with older people may require age-relevant adaptations, such as using repetition, rehearsal and presenting information in different modalities to compensate for cognitive or sensory problems ${ }^{10}$.

This review aims to address a gap in the literature by specifically identifying studies that have assessed the effects of psychosocial interventions on social functioning in people with severe mental illness during the later stages of the life span. We aim to describe the interventions that were delivered in the studies and report the effectiveness of interventions in terms of social functioning outcomes. In line with a substantial number of studies that target people with schizophrenia in later life, we aimed to include studies targeting people with schizophrenia and other related non-affective psychotic disorders and studies targeting people in both middle and old age. There may be differences between those in middle-age and later life (for example, those in middle-age may have less cognitive or sensory problems). However, research in this field tends to include middle-aged participants on the basis that people with severe mental illness have a reduced life expectancy of 20 years ${ }^{11}$ and consequently may show signs of premature ageing. Previous research also suggests that even in 'healthy' people, age-related changes and issues become relevant and salient in midlife ${ }^{12}$.

\section{Method}




\section{Eligibility criteria}

Eligible criteria included: (i) publication in a peer-reviewed journal article, (ii) written in the English language, (iii) a quantitative methodology, (iv) evaluation of a psychosocial intervention, (v) a validated measure of social functioning, and (vi) participants with a diagnosis of a non-affective psychotic disorder aged 40 and above.

Studies were included that had examined participants with a Diagnostic and Statistical Manual of Mental Disorders (DSM) or International Statistical Classification of Diseases and Related Health Problems (ICD) diagnosis of any non-affective psychotic disorder or psychotic disorder not otherwise specified. Studies that had included people with severe mental illness (SMI) were eligible where the sample included a minimum of $20 \%$ of participants who had the aforementioned diagnoses.

Psychosocial interventions were defined as 'any intervention that emphasised psychological or social factors rather than biological factors, ${ }^{13, \mathrm{p} .2}$. This definition encompasses psychological interventions, health education interventions, as well as interventions with a focus on social aspects, such as social support. Physical interventions that included psychosocial components were not included, if the primary focus was to target biological chemical mechanisms, for example, medications to improve sleep. Psychosocial interventions could be group or individual.

Social functioning was defined as 'the interaction of an individual with their environment and the ability to fulfil their role within the environment. An individual functions daily within several environments: work, social and leisure, marital, parental, and with the extended family $^{\text {, 14, p. } 63}$. Social functioning measures included in the review were defined as any 
measure relating to the frequency of, quality of, or satisfaction with social, academic or occupational activity. This included socially useful activities, personal and social relationships and self-care.

Studies were excluded if they were case studies or had a qualitative design.

\section{Search Strategy}

Five databases (Medline, Web of Science, PsychINFO, Embase and CINAHL) were systematically searched from inception to December 2017. Words relating to each concept were combined using the OR operator for terms within a concept, and AND between concepts i.e. (psychosocial intervention) AND (older people) AND (psychosis). The full search strategy was initially developed for PsycINFO (see Table.1), then modified and dependant on specific databases.

This search resulted in 10,284 citations with 7,263 citations after duplicates were removed. Ten percent $(n=726)$ were screened at title and abstract level by the lead author and an independent reviewer. A high level of agreement (98\% agreement, $\kappa=0.77)$ was achieved, indicating good inter-rater reliability, and so the remaining titles and abstracts were searched by the lead author only. The remaining 418 citations were screened at full text level against the specified inclusion criteria, with ten percent also screened $(n=42)$ by the postgraduate student $(88 \%$ agreement, $\kappa=0.71)$. Any discrepancies between raters were resolved through discussion until agreement was reached about their inclusion or exclusion in the review. After full text articles were reviewed by the lead author, 401 articles were excluded for not meeting inclusion criteria, with agreement from the research team, resulting in 17 included articles (see Figure 1. flow diagram). Reference lists of papers meeting the inclusion criteria were also searched and any relevant papers were checked for eligibility. 


\section{Data Extraction}

Pertinent information about the studies was extracted including: (i) sample size and characteristics (ii) study design, (iii) intervention description, (iv) social functioning measure(s) used, (v) relevant statistics/findings, and (vi) country. Authors were contacted for any additional information in these categories that was not supplied in the papers themselves.

\section{Quality Assessment}

The quality of studies was assessed using the Effective Public Health Practice Project (EPHPP) Quality Assessment Tool for Quantitative Studies (Thomas et al 2004) ${ }^{15}$ which has previously shown to have good reliability and validity (Thomas et al 2004; Armijo-Olivo et al 2012) ) $^{15,16}$. The lead author and a second reviewer independently rated all papers, with considerable agreement found for overall ratings $(82 \%$ level of agreement, $\kappa=0.69)$. As above, discrepancies between raters were discussed until complete agreement was achieved.

\section{Data Synthesis}

There was a large degree of heterogeneity in the methodology of studies and type of social functioning measure used. A narrative synthesis of the literature was therefore conducted as opposed to a meta-analysis. Effect sizes of individual studies were, however, calculated and reported where data were available.

[Insert Table 1 here]

[Insert Figure 1 here]

\section{Results}




\section{Study characteristics}

Seventeen articles ${ }^{22-38}$, describing fifteen different studies were included in the review. The significant proportion of the work was carried out by three research groups in the US and studies from these groups ranged from pilot studies, full powered RCTs, follow-ups or adaptions to their interventions. Three studies were carried out by Granholm and colleagues ${ }^{24,}$ ${ }^{25,29}$ who developed the 'Cognitive Behaviour Social Skills Training' (CBSST) intervention. Three studies were carried out by Patterson and colleagues ${ }^{22,23,36}$ who developed the Functional Adaptive Skills Training (FAST) intervention and three studies were carried out by Bartels and colleagues ${ }^{32,33,35}$ who developed the Helping Older People Experience Success (HOPES) intervention.

The study characteristics are presented in Table 2 . Seven $22-24,29,32,34,36$ studies were randomised controlled trials (RCTs). Two studies were controlled trials ${ }^{30,31}$ without randomisation and the remaining six studies were within group pre-post test designs ${ }^{25-28,35,37}$. Most of the studies had small samples ranging from 10-79 participants ${ }^{22-31,34,35,37,38}$.Three studies included larger sample sizes $(n=183-240)^{22,32,33}$. Seven studies ${ }^{22,24,26,28-30}$ solely included participants with psychosis-related disorders, whereas the remaining studies included patients with affective diagnoses such as major depression and bipolar disorder. Types of intervention included were: multi component skills training $22,23.31,32,34,37$ integrated mental and physical health interventions $\mathrm{s}^{26,30,31,34,37}$ cognitive remediation $^{28}$, role development ${ }^{27}$, social support $^{38}$ and animal assisted therapy ${ }^{30}$. Interventions were delivered in group ${ }^{22-26,28-31,36,37}$, group and individual together $27,32,31$ and individual ${ }^{34,35,38}$ formats. The majority of studies were conducted in the USA ${ }^{22-4,27,29,31-36,38}$. Other countries of origin included the U.K ${ }^{26}$, Canada $^{28}$ and Israel $^{30}$. 


\section{[Insert Table 2]}

\section{Measures of social functioning}

Measures of social functioning varied across the studies (Table 3.). The most frequently reported measures were: the Independent Living Skills Survey (ILSS $\left.{ }^{17}\right)^{24-26,29,31,32-35}$; USCD Performance-Based Skills Assessment (UPSA $\left.{ }^{18}\right)^{22-25,28,32,33,35,36 ;}$ the Social Skills Performance Assessment $\left(\mathrm{SSPA}^{19}\right)^{22,35-37}$; the Social Behaviour Schedule $\left(\mathrm{SBS}^{20}\right)^{26,31-33}$ and the Multnomah Community Ability Scale $\left(\mathrm{MCAS}^{21}\right)^{32-35}$. Functioning was measured from both self $^{24-26,29,31-33,35}$, performance $22-25,28,32,33.35-37$, observer ${ }^{26,2731-33,38}$ and informant perspectives $26,27,32-35$.

\section{[Insert Table 3]}

\section{Quality assessment (Table 4)}

Overall, four papers were rated as having 'strong' quality ${ }^{22-25}$; ten papers were rated

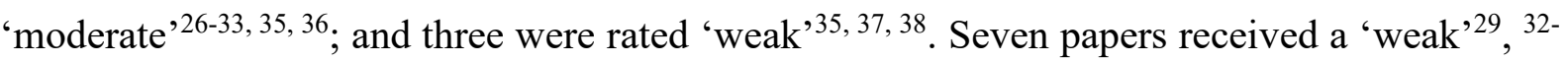
$35,37,38$ rating for selection bias due to lack of sufficient detail about recruitment processes, reliance on self-referrals or poor uptake for eleven papers (eight studies, ${ }^{22-25,29-34,36}$ ), ten papers (seven studies) ${ }^{22-25,29,31-34,38}$, considered confounders between groups either in the design and/or analyses, and so were given 'strong' ratings for this criterion. Two studies received a 'weak' rating for confounders as they did not report controlling for confounders in their design or analyses. 'Strong' ratings were given to all the studies for data collection methods, as they used reliable and valid measures. All the studies reported retention rates of $>60 \%$ at the final time point and received 'strong',22,23,25,27,30,31,36,38 or 'moderate" $24,26,28,29,32-35,37$ ratings for this criterion. 


\section{[Insert Table 4]}

\section{Interventions}

\section{Skills training interventions}

Eight studies ( $n=9$ papers) ${ }^{22-29,36}$ reported interventions that were primarily focused on skills training. Six studies ( $\mathrm{n}=7$ papers) investigated multicomponent skills training groups ${ }^{22-26,29,36}$ and the other two studies focussed on developing skills in one domain; cognitive remediation $^{28}$ and role development ${ }^{27}$.

The FAST intervention was utilised in three studies ${ }^{22,23,36}$ and the CBSST intervention was used in two of the studies ${ }^{24,25,29}$. Both FAST and CBSST are group-based skills training interventions that have been specifically adapted for middle to older age adults with SMI to accommodate age-related factors, such as increased cognitive impairment. The studies included similar module topics targeting social functioning and independent living skills rather than psychiatric symptoms. Whilst Patterson et al. have primarily focused on teaching everyday living skills through a behavioural-based functional adaptation skills training intervention $^{22,23,36}$, the CBSST program led by Granholm and colleagues has a greater focus on the use of cognitive behavioural therapy techniques in combination with social skills training ${ }^{24,25,29}$. Berry and colleagues ${ }^{, 26}$ UK-based study involved a group intervention adapted from the aforementioned US manuals. The group modules focussed on social and daily living skills and incorporated behavioural and cognitive techniques to bolster skill development and practice.

Six studies (7 papers) $)^{22-25,27,29,36}$ found significant effects of the intervention on social functioning, reporting small to large effect sizes (0.11-1.68) which were maintained until 
follow-ups ranging from 6-12 months ${ }^{23-25}$. Three of these studies (4 papers) ${ }^{22,24,25,29}$ were RCTs; one had a large sample $\mathrm{n}=240^{22}$ and the other two ( 3 papers) were moderately sized $\mathrm{n}=76-79{ }^{24,25,29}$, with 'strong' to 'moderate' quality ratings. Of the other studies to report significant effects, two were small feasibility pilot trials of the larger RCT $n=29-40,{ }^{23,36}$ and three were a one group pre-post design $\mathrm{n}=10-24^{26-28}$.

The large $\mathrm{RCT}^{22}$ reported significant improvements in performance-based measures of social functioning (UPSA and SSPA) as compared to TAU and an attentional control comparison group, whilst the smaller RCT (2 papers) ${ }^{24,25}$ did not find statistically significant differences on UPSA scores. However, Granholm et al. ${ }^{29}$ did report significant improvement in selfreported measures of social functioning (ILSS) between the treatment (CBSST) and control group (GFSC).

The two studies that did not find significant effects of intervention on social functioning 26,28 were both pilot feasibility studies so sample size was very small $n=18^{26}, n=24^{28}$ and they were underpowered to detect small effects.

\section{Integrated mental and physical health interventions}

Five studies (6 papers) ${ }^{31-35,37}$ described psychosocial rehabilitation programs, which focus on the improvement of physical health skills either solely ${ }^{37}$ or in combination with skills training around mental health ${ }^{31-35}$. The premise of these interventions are based on evidence that older adults with SMI frequently have physical health co-morbidities which are often exacerbated by poor health maintenance behaviours ${ }^{39}$. 
Three of these studies reported on the effectiveness of the HOPES intervention both in group $(\mathrm{n}=2)^{32,33}$ and individual $(\mathrm{n}=1)^{35}$ format. HOPES is an intensive 2 year program combining weekly social and health skills training groups with monthly $1: 1$ meetings with a nurse. This has been adapted for individuals (HOPES-I) ${ }^{35}$ in which only five of the seven HOPES modules are offered; individuals can select to partake in different modules based on preference. The remaining two studies described the effectiveness of the Integrated- Illness Management and Recovery (I-IMR) intervention ${ }^{34}$ which is a is a 1:1 intervention which combines a traditional self-management program with psychiatric self-management skills and the Collaborative Activation Training for Primary Care (CAT-PC) ${ }^{36}$ which is a group-based intervention which solely focusses on physical healthcare management for people with SMI.

Four studies (5 papers) ${ }^{31-33,35,37}$ found significant improvements in social functioning, reporting small to large treatment effects $(0.25-0.84)$. One study ${ }^{34}$ did not find a significant effect of treatment on social functioning. However it was a feasibility study and sample was small $(n=71)$, suggesting it may be underpowered to detect significant effects

Of the four studies (5 papers) ${ }^{31-33,35,37}$ that reported significant results; one study was an RCT 32,33, one was the pilot study to the $\mathrm{RCT}^{35}$ and the other two studies were a pre-post design ${ }^{34}$, 37. The RCT $n=183^{32,33}$, found improvements across a range of social functioning measures at both 2 and 3 year follow-up. These findings were replicated across participants enrolled in another study which adapted the same intervention in an individual rather than group format $^{35}$. In contrast to the RCT, the two pre-post-test design studies ${ }^{35,37}$ measured social functioning using a performance measure of social skills (SSPA) specifically adapted to include assessment of participants' communication in a medical setting. Both studies found significant improvement in scores of social skills performance following intervention. One of 
the studies ${ }^{35}$ found significant changes to participant performance across subscales measuring social skills and the 'reporting physical symptoms'. The other study ${ }^{37}$ only reported changes in regards to 'overall communication' and 'focus', but did not identify significant findings in relation to any of the medical communication skills. However, this was a pilot feasibility study and underpowered to detect relatively small effects $(n=23)$.

\section{Other interventions}

\section{Social support}

One study ${ }^{38}$ looked at the effects of social support on leisure activities and non-relative social contacts (Lehman's Quality of Life subscales). They used a matched pair design to compare ten participants receiving social support from companions with ten participants who just received standard community treatment. However, due to attrition in the comparison group, only within-group analysis was possible. They found a significant increase in daily activities and non-family contact from baseline to six months, but this was not maintained at 12months.

\section{Animal-assisted therapy}

One study ${ }^{30}$ assessed the effects of animal-assisted therapy (AAT) on in-patients with chronic schizophrenia. The AAT intervention involved 4-hour weekly sessions whereby participants cared for the animals (i.e. grooming, petting etc.) and walked the animals within the hospital grounds. The study benefited from a comparison control group that met to discuss 'current news'. Results suggested that, compared to the control group, the AAT group improved on the Social- Adaptive Functioning Evaluation (SAFE) scale at 6 months $(\mathrm{d}=1.87)$, which was maintained at 12 months. Whilst the study reports preliminary evidence for AAT, it had a very small sample size $(n=20)$, thus limiting generalisability. 


\section{Discussion}

The aim of this systematic review was to examine the effects of psychosocial interventions on the social functioning of middle to older aged adults with severe mental health problems. Seventeen papers representing 15 studies were identified. Overall, these studies found improvements in social functioning for this population across the range of interventions examined, with effects maintained to follow ups ranging from 12 weeks to 12 months $(d=0.11-1.87)$. The potential benefits of psychosocial interventions on social functioning for older and middle-aged adults with severe mental health problems is important given that this patient group report high levels of need in this area ${ }^{10}$ and suggests that these interventions should be routinely offered as part of their care package.

Skills training interventions and in particular multi-component programmes focused on social and daily living skills, using either cognitive or behavioural techniques and delivered in groups has the strongest evidence base. However, evidence from the higher quality RCT studies is mixed in terms of which specific social functioning outcomes are responsive to intervention. Whilst the FAST intervention demonstrated improvement across performance measures of social functioning ${ }^{22}$, the CBSST intervention group only demonstrated improvement in social functioning on self-report measures that have a greater risk of response bias ${ }^{40}$. The two CBSST studies ${ }^{24,25,29}$ were, however, much smaller than the FAST RCT ${ }^{22}$ so may have been less able to detect smaller effects.

There is also good evidence to suggest that integrated physical and mental health interventions are effective in improving social functioning for this patient group, both in group and individual formats ${ }^{31-33,35,37}$ and that these effects were maintained into long term 
follow-ups ranging from six months to three years. However, of the five studies ( 6 papers $)^{31-}$ ${ }^{35,37}$ included in the review, three were pilot studies ${ }^{31,35,37}$ which had small sample sizes. The largest RCT ( $\mathrm{n}=183$; HOPES intervention $)^{32,33}$ reported promising effects of a physical and mental health intervention across self-report, performance and observer measures of social functioning.

There was encouraging preliminary evidence from the study of AAT for improving social functioning in older adults with enduring schizophrenia ${ }^{30}$. However, these results cannot be overstated, given the small sample size used and absence of any long-term follow up. It is noteworthy that evidence from a recent review of $\mathrm{AAT}^{41}$ in various populations was unable to make definitive conclusions and recommended higher quality, larger scale research in this area. Whilst psychosocial interventions that focus on social support for older adults with SMI seem to improve social functioning in theory, there is currently no good evidence to fully support this.

\section{Limitations of current review}

The current review has a number of limitations. Firstly, it excluded studies not written in the English language and grey literature. As there is a limited amount of research looking at older adult populations with psychosis, the review included patients with severe mental illness, including bipolar disorder and patients in middle-age, increasing the heterogeneity of the included samples.

The use of quality assessment tools allows for comparison of studies and the evaluation of study methodology. Nevertheless, the use of a quality assessment tool inevitably involves a degree of subjectivity in the rating process ${ }^{42}$. Whilst, the EPHPP can be applied to a wide 
range of studies, it is best suited to rating RCTs and does not take sample size into account in the final quality rating.

The lack of consistency in social functioning measures was evident across the studies included in the review is noteworthy and further complicated the process of interpreting findings. Some of the measures focus on ability or capacity to engage in life activities (ILSS, UPSA), whereas other measures focus on more interpersonal aspects of social functioning (SBS, SSPA).

\section{Future research implications}

As highlighted above skills training, mostly in a group format, can be an effective means of improving social outcomes for older people. However, there is a lack of research evaluating other more widely established interventions for psychosis in this particular patient group, including Cognitive Behavioural Therapy (in the absence of a social skills component) and Family Therapy.

In general, further research with more robust designs is warranted to determine which elements of the above or current interventions work for older people with severe mental health problems and for whom they work best. Finally, the majority of studies in the review did not state whether participants had late or early onset psychosis (although those few that did described participants as having experienced psychosis over a number of years ${ }^{22-28}$ ). Future research should specify if participants have experienced early or late onset psychosis, as the features and experiences of people with these diagnoses may qualitatively differ, which in turn could impact the effectiveness of interventions for these groups of people ${ }^{43}$. 


\section{Conclusions}

This is the first review to summarise studies investigating social functioning in psychosocial interventions for middle to older aged people with severe mental health problems. Whilst there is some evidence to support the use of skills training interventions and integrated mental and physical health interventions, the research is in its infancy, as is demonstrated by the proportion of pilot feasibility studies included in this review. Given that the overall population of older people is increasing, and that older people with severe mental health problems represent a significant proportion of this population, it is vital that research in this area becomes a priority.

\section{References}


1. Vos T, Barber, B. , Bell, R.M., Bertozzi-Villa,A. , Biryukov, S., Bolliger,I. , F., Charlson, A., Davis, Degenhardt, L., Dicker D. . Global, regional, and national incidence, prevalence, and years lived with disability for 301 acute and chronic diseases and injuries in 188 countries, 1990-2013: a systematic analysis for the Global Burden of Disease Study 2013. The Lancet. 2015;386(9995):743-800.

2. Cohen $\mathrm{Cl}$, Vahia I, Reyes $\mathrm{P}$, et al. Focus on geriatric psychiatry: schizophrenia in later life: clinical symptoms and social well-being. Psychiatric Services. 2008;59(3):232-234.

3. Leucht S, Komossa K, Rummel-Kluge C, et al. A Meta-Analysis of Head-to-Head Comparisons of Second-Generation Antipsychotics in the Treatment of Schizophrenia. American Journal of Psychiatry. 2009;166(2):152-163.

4. Arango C, Garibaldi G, Marder SR. Pharmacological approaches to treating negative symptoms: a review of clinical trials. Schizophrenia Research. 2013;150(2):346-352.

5. Lutgens D, Gariepy G, Malla A. Psychological and psychosocial interventions for negative symptoms in psychosis: systematic review and meta-analysis. British Journal of Psychiatry. 2017;210(5):324-332.

6. Sable JA, Jeste DV. Antipsychotic treatment for late-life schizophrenia. Current Psychiatry Reports. 2002;4(4):299-306.

7. Martin EA, Ongur D, Cohen BM, Lewandowski KE. Social functioning and age across affective and nonaffective psychoses. Journal of Nervous and Mental Disease. 2015;203(1):37-42.

8. Pestana Santos A, Amílcar Teixeira J. Psychosocial interventions for schizophrenia. European Psychiatry. 2016;33:S725.

9. Wykes T, Steel C, Everitt B, Tarrier N. Cognitive behavior therapy for schizophrenia: Effect sizes, clinical models, and methodological rigor. Schizophrenia Bulletin. 2008;34(3):523-537.

10. Berry K, Barrowclough C. The needs of older adults with schizophrenia: Implications for psychological interventions. Clinical Psychology Review. 2009;29(1):68-76.

11. NICE (2014). Psychosis and schizophrenia in adults: prevention and management. Retrieved from https://www.nice.org.uk/guidance/cg178.

12. Brown, L., Bowden, S., Bryant, C., Brown, V., Bei, B., Gilson, K. M., Komiti, A., \& Judd, F. (2015). Validation and utility of the Attitudes to Ageing Questionnaire: links to menopause and well-being trajectories. Maturitas, 82, 190-196

13. Ruddy R, House AAO. Psychosocial interventions for conversion disorder. Cochrane Database of Systematic Reviews. 2005(2)

14. Bosc M. Assessment of social functioning in depression. Comprehensive Psychiatry. 2000;41(1):63-69.

15. Thomas B, Ciliska D, Dobbins M, Micucci S. A process for systematically reviewing the literature: providing the research evidence for public health nursing interventions. Worldviews on Evidence-Based Nursing. 2004;1(3):176-184.

16. Armijo-Olivo S, Stiles CR, Hagen NA, Biondo PD, Cummings GG. Assessment of study quality for systematic reviews: a comparison of the Cochrane Collaboration Risk of Bias Tool and the Effective Public Health Practice Project Quality Assessment Tool: methodological research. Journal of Evaluation in Clinical Practice. 2012;18(1):12-18.

17. Wallace CJ, Liberman RP, Tauber R, Wallace J. The Independent Living Skills Survey: a comprehensive measure of the community functioning of severely and persistently mentally ill individuals. Schizophrenia Bulletin. 2000;26(3):631-658.

18. Patterson TL, Goldman S, McKibbin CL, Hughs T, Jeste DV. USCD performance-based skills assessment: Development of a new measure of everyday functioning for severely mentally ill adults. Schizophrenia Bulletin. 2001;27(2):235.

19. Patterson TL, Moscona S, McKibbin CL, Davidson K, Jeste DV. Social skills performance assessment among older patients with schizophrenia. Schizophrenia Research. 2001;48(23):351-360. 
20. Wykes T, Sturt E. The measurement of social behaviour in psychiatric patients: an assessment of the reliability and validity of the SBS schedule. The British Journal of Psychiatry. 1986;148(1):1-11.

21. Barker S, Barron N, McFarland BH, Bigelow DA. A community ability scale for chronically mentally ill consumers: Part I. Reliability and validity. Community mMental Health Journal. 1994;30(4):363-383.

22. Patterson TL, Mausbach BT, McKibbin C, Goldman S, Bucardo J, Jeste DV. Functional Adaptation Skills Training (FAST): A randomized trial of a psychosocial intervention for middle-aged and older patients with chronic psychotic disorders. Schizophrenia Research. 2006;86(1-3):291-299.

23. Patterson TL, McKibbin C, Taylor M, et al. Functional adaptation skills training (FAST): a pilot psychosocial intervention study in middle-aged and older patients with chronic psychotic disorders. American Journal of Geriatric Psychiatry. 2003;11(1):17-23.

24. Granholm E, McQuaid JR, McClure FS, et al. A randomized, controlled trial of cognitive behaviors social skills training for middle-aged and older outpatients with chronic schizophrenia. American Journal of Psychiatry. 2005;162(3):520-529.

25. Granholm E, McQuaid JR, McClure FS, et al. Randomized controlled trial of cognitive behavioral social skills training for older people with schizophrenia: 12-month follow-up. The Journal of Clinical Psychiatry. 2007;68(5):730-737.

26. Berry K, Purandare N, Drake R, Elmsley R, Jones L, Barrowclough C. A mixed-methods evaluation of a pilot psychosocial intervention group for older people with schizophrenia. Behavioural and Cognitive Psychotherapy. 2014;42(2):199-210.

27. Schindler V, LaGuardia R, Melchiorre S, Bailey H. Role development: an evidence-based intervention to develop roles and skills in clients with mental illness. OT Practice. 2004;9(21):16-20.

28. Golas AC, Kalache SM, Tsoutsoulas C, Mulsant BH, Bowie CR, Rajji TK. Cognitive remediation for older community-dwelling individuals with schizophrenia: A pilot and feasibility study. International Journal of Geriatric Psychiatry. 2015;30(11):1129-1134.

29. Granholm E, Holden J, Link PC, McQuaid JR, Jeste DV. Randomized controlled trial of cognitive behavioral social skills training for older consumers with schizophrenia: defeatist performance attitudes and functional outcome. American Journal of Geriatric Psychiatry. 2013;21(3):251-262.

30. Barak Y, Savorai O, Mavashev S, Beni A. Animal-assisted therapy for elderly schizophrenic patients: A one-year controlled trial. American Journal of Geriatric Psychiatry. 2001;9(4):439442.

31. Bartels SJ, Forester B, Mueser KT, et al. Enhanced skills training and health care management for older persons with severe mental illness. Community Mental Health Journal. 2004;40(1):75-90.

32. Mueser KT, Pratt SI, Bartels SJ, et al. Randomized trial of social rehabilitation and integrated health care for older people with severe mental illness. Journal of Consulting and Clinical Psychology. 2010;78(4):561-573.

33. Bartels SJ, Pratt SI, Mueser KT, et al. Long-term outcomes of a randomized trial of integrated skills training and preventive healthcare for older adults with serious mental illness. The American Journal of Geriatric Psychiatry. 2014;22(11):1251-1261.

34. Bartels SJ, Pratt SI, Mueser KT, et al. Integrated IMR for psychiatric and general medical illness for adults aged 50 or older with serious mental illness. Psychiatric Services (Washington, DC). 2014;65(3):330-337.

35. Pratt SI, Mueser KT, Wolfe R, Santos MM, Bartels SJ. One size doesn't fit all: A trial of individually tailored skills training. Psychiatric Rehabilitation Journal. 2017:No Pagination Specified. 
36. Patterson TL, Bucardo J, McKibbin CL, et al. Development and pilot testing of a new psychosocial intervention for older Latinos with chronic psychosis. Schizophrenia Bulletin. 2005;31(4):922-930.

37. Bartels SJ, Aschbrenner KA, Rolin SA, Cimpean Hendrick D, Naslund JA, Faber MJ. Activating Older Adults With Serious Mental Illness for Collaborative Primary Care Visits. Psychiatric Rehabilitation Journal. 2013;36(4):278-288.

38. Gammonley D. A lay helper intervention for rural elders with severe mental illness. Social Work in Mental Health. 2006;4(4):1-19.

39.. Druss BG, Bradford WD, Rosenheck RA, Radford MJ, Krumholz HM. Quality of medical care and excess mortality in older patients with mental disorders. Archives of General Psychiatry. 2001;58(6):565-572.

40. Arnold HJ, Feldman DC. Social desirability response bias in self-report choice situations. Academy of Management Journal. 1981;24(2):377-385.

41. Kamioka H, Okada S, Tsutani $\mathrm{K}, \underline{\text { Park } \mathrm{H}}, \underline{\text { Okuizumi } \mathrm{H}}, \underline{\text { Handa S }}$ Oshio T, Park SJ, Kitayuguchi $\mathrm{J}$, Abe T, Honda T, Mutoh Y. Effectiveness of animal-assisted therapy: A systematic review of

42. Higgins JPT, Altman DG, Gøtzsche PC, et al. The Cochrane Collaboration's tool for assessing risk of bias in randomised trials. British Medical Journal. 2011;343:d5928.

43.. $\quad$ Yeon BK, Hong N. Late-onset psychosis. Psychiatry Investigation. 2007;4(1):9. 
Tables

Table 1. Search strategy for PSYCINFO database

\begin{tabular}{|c|c|c|}
\hline \multicolumn{3}{|c|}{ Keywords } \\
\hline Psychosocial & Older adults & Psychosis \\
\hline psychotherap* & Old* adult* & Psychos*s \\
\hline $\begin{array}{l}\text { psycholog* ADJ3 (therap* OR } \\
\text { intervention OR treatment) }\end{array}$ & Old* people & Psychotic \\
\hline $\begin{array}{l}\text { psychosocial ADJ3 (therap* OR } \\
\text { intervention OR treatment) }\end{array}$ & Later life & Schizo* \\
\hline counsel* & Elderly & Delusional disorder \\
\hline Cognitive Behav* Therapy & Older person* & $\begin{array}{l}\text { (chronic* OR serious* OR sever*) ADJ3 } \\
((\text { mental OR psycho*)ADJ1 (ill* OR disorder*)) }\end{array}$ \\
\hline $\mathrm{cbt}$ & middle age* & \\
\hline \multicolumn{3}{|l|}{ non-pharmacologic* } \\
\hline \multicolumn{3}{|l|}{ non-pharmaceutic* } \\
\hline \multicolumn{3}{|l|}{ skills training } \\
\hline \multicolumn{3}{|l|}{ social skills } \\
\hline \multirow{2}{*}{\multicolumn{3}{|c|}{$\begin{array}{l}\text { cognitive remediation therapy } \\
\text { social support }\end{array}$}} \\
\hline & & \\
\hline \multicolumn{3}{|c|}{ MeSH terms } \\
\hline Group psychotherapy & Gerontology & Schizophrenia \\
\hline Psychotherapy & Geriatrics & Psychosis \\
\hline Counseling & $\begin{array}{l}\text { Geriatric } \\
\text { patients }\end{array}$ & \\
\hline Cognitive Behavior Therapy & $\begin{array}{l}\text { Aged } \\
\text { "Attitudes } \\
\text { Towards" }\end{array}$ & \\
\hline Cognitive Therapy & Aging & \\
\hline \multicolumn{3}{|l|}{ Online Therapy } \\
\hline \multicolumn{3}{|l|}{ Computer assisted therapy } \\
\hline \multicolumn{3}{|l|}{ Social Skills } \\
\hline \multicolumn{3}{|l|}{ Social Skills Training } \\
\hline \multicolumn{3}{|l|}{ Communication Skills Training } \\
\hline \multicolumn{3}{|l|}{ Skill Learning } \\
\hline \multicolumn{3}{|l|}{ Dialectical Behavior Therapy } \\
\hline \multicolumn{3}{|l|}{ Psychosocial Rehabilitation } \\
\hline \multicolumn{3}{|l|}{ Cognitive Rehabilitation } \\
\hline \multicolumn{3}{|l|}{ Social support } \\
\hline Mental health services & & \\
\hline
\end{tabular}


Figure 1. PRISMA diagram
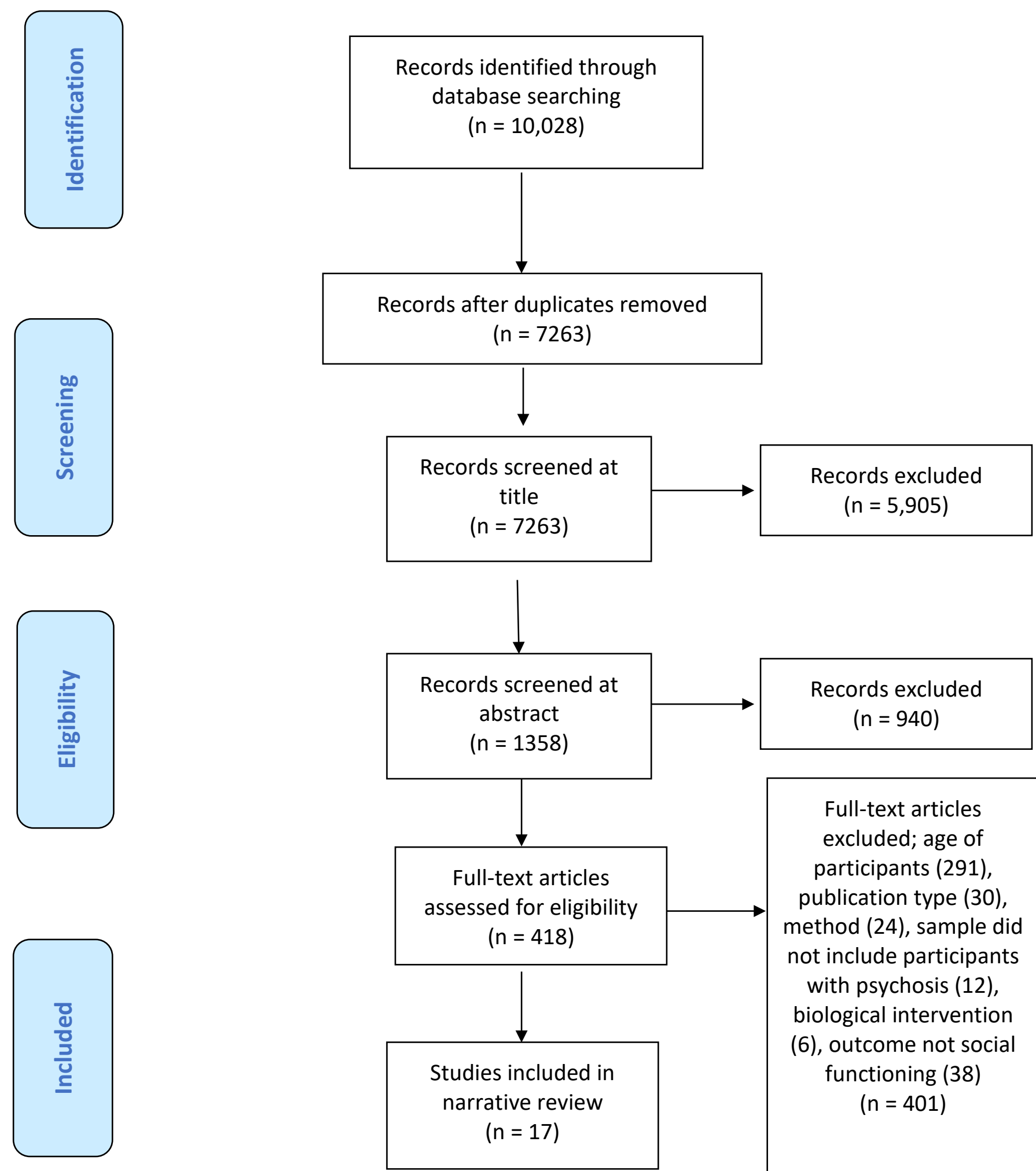

Records excluded $(n=940)$

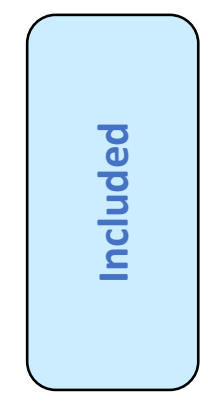

tudies included in

$$
(n=17)
$$

Full-text articles excluded; age of participants (291), publication type (30), method (24), sample did not include participants with psychosis (12), biological intervention (6), outcome not social functioning (38)

$$
(n=401)
$$


Table 2. Study Characteristics

\begin{tabular}{|c|c|c|c|c|c|c|c|c|}
\hline Study & $\begin{array}{c}\text { Countr } \\
y\end{array}$ & Design & Sample & Intervention & $\begin{array}{c}\text { Comparison } \\
\text { group }\end{array}$ & $\begin{array}{c}\text { Social } \\
\text { functioning } \\
\text { measure }\end{array}$ & $\begin{array}{l}\text { Follo } \\
\text { w-up }\end{array}$ & Key Findings \\
\hline \multicolumn{9}{|l|}{ Skills training interventions: } \\
\hline $\begin{array}{l}\text { Granholm, McQuaid, } \\
\text { McClure, Auslander, } \\
\text { Perivoliotis, Pedrelli, } \\
\text { Patterson, Jesfe }{ }^{24} \\
\text { A Randomized, Controlled } \\
\text { Trial of Cognitive } \\
\text { Behavioral Social Skills } \\
\text { Training for Middle-Aged } \\
\text { and Older Outpatients } \\
\text { With Chronic } \\
\text { Schizophrenia }\end{array}$ & USA & RCT & $\begin{array}{l}\mathrm{n}=76 \text { adults } \\
\text { aged } 42-74 \text { years } \\
\text { with chronic } \\
\text { schizophrenia. } \\
\text { Schizophrenia } \\
(63 \%) \\
\text { schizoaffective } \\
(37 \%)\end{array}$ & $\begin{array}{l}\text { CBSST } 24 \mathrm{x} \text { weekly } 2 \mathrm{hr} \text { sessions. } \\
\text { The intervention integrates CBT } \\
\text { and SST interventions and modifies } \\
\text { these interventions for use with } \\
\text { older patients with psychosis. }\end{array}$ & TAU & $\begin{array}{l}\text { ILSS }^{\text {self }} \\
\text { UPSA }\end{array}$ & $\begin{array}{l}6 \mathrm{M} \\
12 \mathrm{M}\end{array}$ & $\begin{array}{l}\text { CBSST intervention group showed } \\
\text { significant improvements on ILSS } \\
\text { measures as compared to TAU which } \\
\text { were maintained at } 12 \mathrm{M}(\mathrm{d}=0.50, \mathrm{p}<0.05) \text {. } \\
\text { There was not a significant difference } \\
\text { between groups on UPSA scores }(\mathrm{d}= \\
0.12) \text {. }\end{array}$ \\
\hline $\begin{array}{l}\text { Granholm et al. (2007) } \\
\text { A Randomized, Controlled } \\
\text { Trial of Cognitive } \\
\text { Behavioral Social Skills } \\
\text { Training for Older People } \\
\text { With Schizophrenia: } 12 \\
\text { Month Follow-Up }\end{array}$ & & & & & & & & \\
\hline $\begin{array}{l}\text { Granholm, Holden, Link, } \\
\text { McQuaid, Jeste } 29 \\
\text { Randomized Controlled } \\
\text { Trial of Cognitive } \\
\text { Behavioral Social Skills } \\
\text { Training for Older } \\
\text { Consumers With } \\
\text { Schizophrenia: Defeatist } \\
\text { Performance Attitudes and } \\
\text { Functional Outcome }\end{array}$ & USA & RCT & $\begin{array}{l}\mathrm{n}=79 \text { adults with } \\
\text { a mean age of } 55 \\
\text { years }(6.6) \text {, range } \\
46-78 \text { years with } \\
\text { schizophrenia or } \\
\text { schizoaffective } \\
\text { disorder. } \\
\text { Schizophrenia } \\
(81 \%) ; \\
\text { schizoaffective } \\
(19 \%)\end{array}$ & $\begin{array}{l}\text { CBSST 36x } 120 \text { min group } \\
\text { sessions. 3x } 6 \text { module sessions } \\
\text { delivered twice over } 9 \text { months. }\end{array}$ & $\begin{array}{l}\text { Goal-focused } \\
\text { supportive } \\
\text { contact } \\
\text { (GFSC) 36x } \\
120 \text { min group } \\
\text { contact } \\
\text { sessions. }\end{array}$ & ILSS $^{\text {self }}$ & $\begin{array}{l}9 \mathrm{M} \\
13.5 \mathrm{M}\end{array}$ & $\begin{array}{l}\text { The CBSST intervention group showed } \\
\text { significant improvements by } 13.5 \mathrm{M} \text { on } \\
\text { ILSS self }(\mathrm{d}=0.29 \mathrm{p}=0.021) \text { compared to } \\
\text { GFSC group .Defeatist performance } \\
\text { attitudes were shown to moderate these } \\
\text { effects. }\end{array}$ \\
\hline
\end{tabular}




\begin{tabular}{|c|c|c|c|c|c|c|c|c|}
\hline $\begin{array}{l}\text { Patterson, McKibbin, } \\
\text { Taylor, Goldman, Davila- } \\
\text { Fragam Bucardo, Jeste }{ }^{23} \\
\text { Functional adaptation } \\
\text { skills training (FAST): A } \\
\text { pilot psychosocial } \\
\text { intervention study in } \\
\text { middle-aged and older } \\
\text { patients with chronic } \\
\text { psychotic disorders }\end{array}$ & USA & $\begin{array}{l}\text { Pilot } \\
\text { RCT }\end{array}$ & $\begin{array}{l}\mathrm{n}=40 \text { adultswith } \\
\text { a mean age of } 45 \\
\text { years (range } 42- \\
69 \text { years) with } \\
\text { psychosis related } \\
\text { disorder. } \\
\text { Schizophrenia } \\
(56 \%) ; \\
\text { schizoaffective } \\
(25 \%) ; \text { mood } \\
\text { disorder with } \\
\text { psychotic } \\
\text { features }(19 \%)\end{array}$ & $\begin{array}{l}\text { FAST is a manualised behavioural } \\
\text { group skills training intervention. It } \\
\text { is a multi-component intervention } \\
\text { covering } 6 \text { areas of functioning. } \\
24 \text { semi-weekly x } 120 \text { min sessions. }\end{array}$ & TAU & UPSA & $\begin{array}{l}12 \mathrm{~W} \\
24 \mathrm{~W}\end{array}$ & $\begin{array}{l}\text { FAST intervention group showed } \\
\text { improvements on UPSA at } 12 \mathrm{~W} \text { and at } \\
24 \mathrm{~W} \text { follow-up }(\mathrm{d}=0.11, \mathrm{p}<0.0016) \\
\text { compared to TAU. }\end{array}$ \\
\hline $\begin{array}{l}\text { Patterson, Mausbach, } \\
\text { McKibbin, Goldman, } \\
\text { Burcardo, Jeste }^{22} \\
\text { Functional Adaptation } \\
\text { Skills Training (FAST): A } \\
\text { randomized trial of a } \\
\text { psychosocial intervention } \\
\text { for middle-aged and older } \\
\text { patients with chronic } \\
\text { psychotic disorders }\end{array}$ & USA & RCT & $\begin{array}{l}\mathrm{n}=240 \text { adults } \\
\text { aged } 40-78 \text { years } \\
\text { with psychosis } \\
\text { related disorders. } \\
\text { Schizophrenia } \\
(80.6 \%) \\
\text { schizoaffective } \\
(19.4 \%)\end{array}$ & Same as above & $\begin{array}{l}\text { Attentional } \\
\text { control group } \\
\text { (AC) }\end{array}$ & $\begin{array}{l}\text { UPSA } \\
\text { SSPA }\end{array}$ & $24 \mathrm{~W}$ & $\begin{array}{l}\text { FAST group intervention showed } \\
\text { improvements at } 24 \mathrm{~W} \text { on: } \mathrm{UPSA}(\mathrm{d}=0.32 \text {, } \\
\mathrm{p}=0.046) \& \text { SSPA }(\mathrm{d}=0.48, \mathrm{p}=0.003) \\
\text { compared to the } \mathrm{AC} \text { group. }\end{array}$ \\
\hline $\begin{array}{l}\text { Patterson, Bucardo, } \\
\text { McKibbin, Mausbach, } \\
\text { Moore, Barrio, Goldman, } \\
\text { Jeste } \\
\text { Development and pilot } \\
\text { testing of a new } \\
\text { psychosocial intervention } \\
\text { for older Latinos with } \\
\text { chronic psychosis }\end{array}$ & USA & $\begin{array}{l}\text { Pilot } \\
\text { RCT }\end{array}$ & $\begin{array}{l}\mathrm{n}=29 \text { adults } \\
\text { aged with } \\
\text { psychosis related } \\
\text { disorders. } \\
\text { Schizophrenia } \\
(57 \%) \\
\text { Schizoaffective } \\
\text { Disorder } 9(43 \%)\end{array}$ & $\begin{array}{l}\text { The FAST program as outlined } \\
\text { above was adapted for a Latino } \\
\text { population 'PEDAL' and measures } \\
\text { and materials were translated into } \\
\text { Spanish by bi-lingual researchers } \\
\text { and was modified to fit with } \\
\text { culturally appropriate scenarios and } \\
\text { roles etc. }\end{array}$ & Support group & $\begin{array}{l}\text { UPSA } \\
\text { SSPA }\end{array}$ & $\begin{array}{l}24 \mathrm{~W} \\
12 \mathrm{M} \\
18 \mathrm{M}\end{array}$ & $\begin{array}{l}\text { PEDAL group intervention showed } \\
\text { improvements at } 24 \mathrm{~W} \text { (post-treatment) } \\
\text { across UPSA scores }(\mathrm{d}=1.68, \mathrm{p}=0.001) \\
\text { compared to the social support } \\
\text { comparison group. There were no } \\
\text { significant differences on UPSA scores } \\
\text { between the groups at } 6 \mathrm{M}(\mathrm{d}=0.80 \text { ) or } \\
12 \mathrm{M}(\mathrm{d}=0.32) \text { There were no significant } \\
\text { differences between the groups on SSPA } \\
\text { scores at any time point }(6 \mathrm{M} \mathrm{d}=0.75 ; \\
12 \mathrm{M} \mathrm{d}=0.48)\end{array}$ \\
\hline $\begin{array}{l}\text { Berry, Purandare, Drake, } \\
\text { Elmsley, Jones, } \\
\text { Barrowclough }{ }^{26} \\
\text { A mixed-methods } \\
\text { evaluation of a pilot } \\
\text { psychosocial intervention } \\
\text { group for older people with } \\
\text { schizophrenia }\end{array}$ & U.K & $\begin{array}{l}\text { Pilot } \\
\text { mixed } \\
\text { methods } \\
\text { pre-post- } \\
\text { test } \\
\text { design }\end{array}$ & $\begin{array}{l}\mathrm{n}=18 \text { adults with } \\
\text { a mean age of } \\
63.43 \text { years } \\
(4.39) \text { with } \\
\text { Schizophrenia } \\
(86 \%) ; \\
\text { schizoaffective - } \\
(14 \%)\end{array}$ & $\begin{array}{l}\text { Based on U.S manuals but adapted } \\
\text { for U.K audience. } 16 \times 2 \text { hr weekly } \\
\text { group sessions. Topics included } \\
\text { strengths, goals, social skills, ADLS } \\
\text { self-care, increasing social contacts, } \\
\text { planning and the future. }\end{array}$ & $\mathrm{n} / \mathrm{a}$ & $\begin{array}{l}\text { ILSS } \\
\text { ILSS } \\
\text { SBSformant } \\
\text { SBS }\end{array}$ & $16 \mathrm{~W}$ & $\begin{array}{l}\text { No significant differences were found } \\
\text { between pre and post measures of social } \\
\text { functioning on: } S B S \text { (median }=40, U=- \\
1.44, p=0.150) ; \text { ILSS } \\
U=-1.52, p=0.128 \text { ) and ILSS } \text { ILelf }^{\text {selan }}=3.29 \text { (median } \\
=0.74, U=-1.86, p=0.063) \text {. }\end{array}$ \\
\hline
\end{tabular}




\begin{tabular}{|c|c|c|c|c|c|c|c|c|}
\hline $\begin{array}{l}\text { Schindler }^{27} \\
\text { Developing roles and skills } \\
\text { in community-living adults } \\
\text { with severe and persistent } \\
\text { mental illness }\end{array}$ & USA & $\begin{array}{l}\text { Pre- } \\
\text { post-test } \\
\text { design }\end{array}$ & $\begin{array}{l}\mathrm{n}=10 \text { adults aged } \\
40-54 \text { years with } \\
\text { SMI. } \\
\text { Schizophrenia } \\
(80 \%) .\end{array}$ & $\begin{array}{l}\text { Occupational therapy intervention. } \\
9 \times \text { weekly sessions. Role } \\
\text { Development (Schindler, 2004), a } \\
\text { set of guidelines for clinical } \\
\text { practice, has been developed to } \\
\text { provide specific direction for health } \\
\text { care practitioners to assist people } \\
\text { diagnosed with severe and } \\
\text { persistent } \\
\text { mental illness to learn social roles } \\
\text { and their underlying task and } \\
\text { interpersonal skills. }\end{array}$ & $\mathrm{n} / \mathrm{a}$ & $\begin{array}{l}\text { Role } \\
\text { functioning } \\
\text { scale(RFS), task } \\
\text { skills scale } \\
\text { (TSS)and the } \\
\text { interpersonal } \\
\text { skills scale } \\
\text { (ISS) }\end{array}$ & $9 \mathrm{~W}$ & $\begin{array}{l}\text { Participant showed significant } \\
\text { improvements on RFS }(\mathrm{d}=0.61, \mathrm{p}=0.008) \text {, } \\
\text { TSS }(\mathrm{d}=0.63, \mathrm{p}=0.50) \text { and ISS scores }(\mathrm{d}= \\
0.84, \mathrm{p}=0.045) \text { post treatment. }\end{array}$ \\
\hline $\begin{array}{l}\text { Golas, Kalache, } \\
\text { Tsoutsoulas, Mulsant, } \\
\text { Bowie, Rajji } 1^{28} \\
\text { Cognitive remediation for } \\
\text { older community-dwelling } \\
\text { individuals with } \\
\text { schizophrenia: A pilot and } \\
\text { feasibility study }\end{array}$ & Canada & $\begin{array}{l}\text { Pre- } \\
\text { post-test } \\
\text { design }\end{array}$ & $\begin{array}{l}\mathrm{n}=22 \text { adults with } \\
\text { a mean age of } \\
69.8 \text { years (5.3) } \\
\text { with } \\
\text { Schizophrenia } \\
\text { or } \\
\text { schizoaffective } \\
\text { disorder( } 100 \%)\end{array}$ & $\begin{array}{l}\text { CR } 8 \times 2 \text { hour weekly therapist } \\
\text { guided session: (1) cognition for } \\
\text { everyday functioning and cognitive } \\
\text { strategies, (2) computerized drills } \\
\text { targeting different cognitive } \\
\text { domains, (3) monitoring to enhance } \\
\text { metacognitive skills, and } \\
\text { (4) how to generalise cognitive } \\
\text { skills } \\
\text { to daily life. }\end{array}$ & $\mathrm{n} / \mathrm{a}$ & UPSA & $8 \mathrm{~W}$ & $\begin{array}{l}\text { CR intervention group did not show any } \\
\text { significant changes in social functioning } \\
\text { post intervention on } \mathrm{UPSA}^{\text {Total }}(\mathrm{d}=0.23 \text {, } \\
\mathrm{p}=0.34)\end{array}$ \\
\hline \multicolumn{9}{|c|}{ Integrated mental and physical health interventions: } \\
\hline $\begin{array}{l}\text { Bartels et al., }(2004):{ }^{31} \\
\text { Enhanced skills training } \\
\text { and health care } \\
\text { management for older } \\
\text { persons with severe mental } \\
\text { illness }\end{array}$ & USA & Pilot CT & $\begin{array}{l}\mathrm{n}=27 \\
\text { Adults with a } \\
\text { mean age of } 65 \\
\text { years }(5.7) \text { with } \\
\text { SMI. } \\
\text { Schizophrenia } \\
(54.2 \%) ; \\
\text { schizoaffective } \\
(12.5 \%) ; \\
\text { psychotic } \\
\text { disorder }(8.3 \%)\end{array}$ & $\begin{array}{l}\text { Multi-component skills training } \\
\text { (ST): } 2 \text { x } 1 \text { hr weekly group } \\
\text { sessions combined with a health } \\
\text { maintenance intervention (HM) }\end{array}$ & $\begin{array}{l}\mathrm{HM} \\
\text { intervention. }\end{array}$ & $\begin{array}{l}\text { ILSS }^{\text {self }} \\
\text { SBS }\end{array}$ & $1 \mathrm{Y}$ & 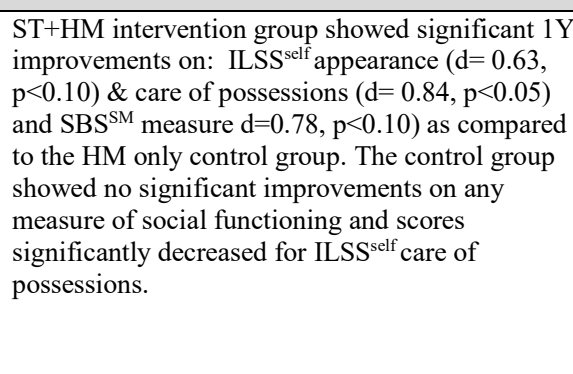 \\
\hline $\begin{array}{l}\text { Mueser, Pratt, Bartels, } \\
\text { Swain, Forester, Cather, } \\
\text { Feldman } 32 \\
\text { Randomized trial of social } \\
\text { rehabilitation and } \\
\text { integrated health care for } \\
\text { older people with severe } \\
\text { mental illness. }\end{array}$ & USA & RCT & $\begin{array}{l}\mathrm{n}=183 \\
\text { adults with a } \\
\text { mean age of } 60.2 \\
\text { years }(7.9) \text { with } \\
\text { SMI. } \\
\text { Schizophrenia } \\
(28 \%) ; \\
\text { schizoaffective } \\
(28 \%) \\
\end{array}$ & $\begin{array}{l}\text { HOPES intervention. Multi- } \\
\text { component social rehabilitation and } \\
\text { health management alongside TAU. } \\
1 \text { st year- weekly skills classes and } \\
2 x \text { monthly } 1: 1 \text { meetings with a } \\
\text { nurse. } 2 \text { nd year } 1 x \text { monthly skills } \\
\text { classes, community practice tips } \\
\text { and meetings with nurse }\end{array}$ & TAU & $\begin{array}{l}\text { UPSA, } \\
\text { MCAS, } \\
\text { SBS } \\
\text { ILSS }^{\text {self }}\end{array}$ & $\begin{array}{l}1 \mathrm{Y} \\
2 \mathrm{Y} \\
3 \mathrm{Y}\end{array}$ & $\begin{array}{l}\text { HOPES intervention group significant } \\
\text { improvements at } 2 Y \text { on: ILSS }{ }^{\text {total }}(\mathrm{d}=0.25 \text {, } \\
\mathrm{p}=0.33) ; \mathrm{MCAS}(\mathrm{d}=0.26, \mathrm{p}=0.024) \text { and } \\
\text { UPSA }(\mathrm{d}=0.45, \mathrm{p}=0.014) \text { as compared to the } \\
\text { TAU group. }\end{array}$ \\
\hline
\end{tabular}


Bartels, Pratt, Mueser,

Forester, Wolfe, Cather,

Xie, McHugo, Bird,

Aschbrenner, Naslund,

Feldman ${ }^{33}$

Long-Term Outcomes of

Randomized Trial of

Integrated Skills Training

and Preventive Healthcare

for Older Adults with

Serious Mental Illness.

Pratt, Mueser, Wolfe,

One Size Doesn't Fit All:

USA Pre-post

$\mathrm{n}=47 \quad$ Adapted HOPES intervention for

individual based program (HOPES-

$\mathrm{n} / \mathrm{a}$

MCAS

mean age of 62

program (HOPES-

LSS $^{\text {sel }}$

SSPA

3M HOPES-I intervention group (where participant

years (6.5) with modules were

UPSA

had baseline deficits) showed significant

A Trial of Individually

SMI.

modules were available with

Schizophrenia participants. Recommended min. 3

improvements at $3 \mathrm{M}$ on MCAS post treatment

$($ mean $=3.64(0.38), \mathrm{t}=2.89, \mathrm{p}=0.012)$ and at $6 \mathrm{M}$

on: $\operatorname{ILSS}^{\mathrm{LR}}(0.417(0.16), \mathrm{F}=14.31,=0.001)$;

$\operatorname{SSPA}^{1}$ (mean 3.3(1.1), $\left.\mathrm{F}=19.88, \mathrm{p}=0.002\right)$

(36\%); full modules over 12 months.

$\operatorname{SSPA}^{2}(\mathrm{mean}=5.0(3.16), \mathrm{F}=42.75, \mathrm{p}<0.001)$;

$\mathrm{SSPA}^{3}($ mean $=3.56(0.58), \mathrm{F}=31.01, \mathrm{p}<0.001)$ and

schizo

UPSA (mean $=72.90(20.5), \mathrm{F}=5.31, \mathrm{p}=0.037)$

Bartels, Aschbrenner, Rolin, Cimpean, Hendrick,

USA

Pre-Post
pilot

$=23$ adults with Multi-component CAT-PC

a mean age of intervention. $9 \times 90$ min group

58.5 years (4.8) sessions delivered weekly over 2

Activating older adults

with serious mental illness

for collaborative primary

care visits

months. Sessions were interactive

skills training around physical with SMI and

cardiovascular

Schizophronia

(41\%);

schizoaffective

$(18 \%)$.

\section{Bartels, Pratt, Mueser, \\ Naslund, Wolfe, Santos, \\ Xie, Riera ${ }^{34}$ \\ Integrated IMR for \\ psychiatric and general \\ aged 50 or older with \\ aged 50 or older with}

USA

RCT

$\mathrm{n}=71$ adults with

a mean age of

60.3 years $(6.5)$

with SMI and

chronic physical

health condition.

Schizophrenia

$\mathrm{n} / \mathrm{a}$

SSPA

CAT-PC intervention was associated with

significant improvement in patient overall

communication performance $(\mathrm{d}=0.66 \mathrm{p}=0.02)$ and

focus $(d=0.58 p=0.06)$. No other significant

effects were found.

Integrated- Illness Management and
Recovery (I-IMR). Multi-
component intervention self-
management skills training for
psychiatric and general medical
illness. 30 x weekly $1: 1$ sessions
with IMR specialist and 15
biweekly sessions with nurse.

TA

TAU

AU

MCAS

$10 \mathrm{M}$,

$14 \mathrm{M}$ - IMR intervention group did not demonstrate with $\operatorname{TAU}(\mathrm{d}=0.26, \mathrm{p}=0.47)$. significantly improved MCAS scores as compared

Other interventions : 


\begin{tabular}{|c|c|c|c|c|c|c|c|c|}
\hline $\begin{array}{l}\text { Barak, Savorai, Mavashev, } \\
\text { Beni }{ }^{30} \\
\text { Animal-assisted therapy } \\
\text { for elderly schizophrenic } \\
\text { patients: A one-year } \\
\text { controlled trial }\end{array}$ & Israel & CT & $\begin{array}{l}\mathrm{n}=20 \text { adults with } \\
\text { a mean age of } \\
79.1 \text { years }(6.7) \\
\text { with } \\
\text { schizophrenia } \\
(100 \%)\end{array}$ & $\begin{array}{l}\text { Weekly } 4 \mathrm{hr} \text { sessions of pet assisted } \\
\text { therapy. Completed ADLs with } \\
\text { animals and walked them outside } \\
\text { hospital grounds. Session concluded } \\
\text { with a summary session at end. }\end{array}$ & $\begin{array}{l}\text { Group met to } \\
\text { discuss current } \\
\text { news }\end{array}$ & SAFE & $\begin{array}{l}6 \mathrm{M} \\
12 \mathrm{M}\end{array}$ & $\begin{array}{l}\text { AAT intervention group showed significant } \\
\text { improvements at } 12 \mathrm{M} \text { on: } \mathrm{SAFE}^{\text {total }} \text { scores } \\
(\mathrm{d}=1.87, \mathrm{p}=0.001) \text { as compared to the control } \\
\text { group. Within-group analysis showed that both } \\
\text { AAT and control group improved on the } \\
\text { instrumental and self-care subscale but this change } \\
\text { was not statistically different between groups. } \\
\text { AAT intervention group improved on SAFE } \\
\text { scores } \\
\text { sores from baseline to } 12 \mathrm{M}(\mathrm{p}=0.001)\end{array}$ \\
\hline
\end{tabular}

\begin{tabular}{|c|c|c|c|c|c|c|}
\hline $\begin{array}{l}\text { Gammonley }^{38} \\
\text { A Lay Helper Intervention } \\
\text { for Rural Elders with } \\
\text { Severe Mental Illness }\end{array}$ & USA & $\begin{array}{l}\text { mixed } \\
\text { methods } \\
\text { pre-post- } \\
\text { test } \\
\text { design }\end{array}$ & $\begin{array}{l}\mathrm{n}=10 \text { adults aged } \\
>60 \text { with SMI. } \\
\text { Schizophrenia } \\
(20 \%) .\end{array}$ & $\begin{array}{l}\text { A social support intervention. It was } \\
\text { a 12-month program whereby lay } \\
\text { helpers were trained to deliver } \\
\text { support to older adult with SMI. } \\
\text { Helpers were paid to provide } \\
\text { companionship and support in a } \\
\text { rural community. }\end{array}$ & TAU & $\begin{array}{l}\text { Leyman's QoL } \\
\text { subscales: } \\
\text { no. daily of } \\
\text { activities and } \\
\text { no. non-relative } \\
\text { activities. }\end{array}$ \\
\hline
\end{tabular}

AAT in to $12 \mathrm{M}(\mathrm{p}=0.001)$

Participants made significant improvements in $0.85(0.44), \mathrm{x}^{2}=4.92, \mathrm{p}=0.23$ ) this plateaued at 12 months and did not reach statistical significance. The number of non-family social contacts decreased from baseline to 6 months, however increased towards baseline after 12 months $\left(\mathrm{mean}=2.90(0.91), \mathrm{x}^{2}=6.22, \mathrm{p}=0.048\right)$.

Note: RCT $=$ Randomised control trial; $\mathrm{CT}=$ controlled trial; $\mathrm{SMI}=$ severe/serious mental illness; $\mathrm{CBSST}=$ cognitive behavioural social skills training; $\mathrm{FAST}=$ functional adaptive skills training; $\mathrm{PEDAL}$
Programa de Entrenamiento para el Desarrollo de Aptitudes para Latinos; $\mathrm{CR}=$ cognitive remediation; $\mathrm{ST}=$ skills training; HM=health management; HOPES=helping older people experience success; Programa de Entrenamiento para el Desarrollo de Aptitudes para Latinos; $\mathrm{CR}=$ cognitive remediation; $\mathrm{ST}=$ =skills training; $\mathrm{HM}=$ health management; HOPES=helping older people experience success;
HOPES-I= helping older people experience success (individual format); CAT-PC= collaborative activation training for primary care; I-IMR=integrated illness management and recovery; AAT= anima assisted therapy; TAU = treatment as usual; GFSC= Goal-focused supportive contact; $\mathrm{AC}=$ attentional control group; ILSS ${ }^{\text {selff }}=$ independent living skills survey (self-report); ILSS $S^{\text {informant }}=$ independent living skills survey (informant); ILSS ${ }^{\mathrm{LR}}=$ independent living skills survey (leisure and recreation subscale); UPSA $=$ UCSD performance based skills assessment ; SSPA= social skills performance assessment ; $\mathrm{SSPA}^{1}=$ social skills performance assessment (role play 1); $\mathrm{SSPA}^{2}=$ social skills performance assessment(role play 2$)$; $\mathrm{SSPA}^{3}=$ social skills performance assessment( role play 3); $\mathrm{SBS}=$ social behaviour schedule; $\mathrm{SBS}{ }^{\mathrm{SM}}=$ social behaviour schedule (social mixing subscale); RFS= Role functioning scale; TSS= task skills scale; ISS= interpersonal skills scale; MCAS= multnomah community ability scale; SAFE= social adaptive functioning evaluation; Leyman's QoL= Leyman's quality of life scale; ADLS= activities of daily living 

Table 3. Description of social functioning scales

\begin{tabular}{|c|c|c|c|}
\hline Measure & Format & Description & Scoring \\
\hline ILSS & $\begin{array}{l}\text { Separate self-report \& } \\
\text { informant rated } \\
\text { available }\end{array}$ & $\begin{array}{l}\text { Measures } 10 \text { domains of basic functional living } \\
\text { skills (e.g. self-care, leisure activities) performed } \\
\text { during the past month. }\end{array}$ & $\begin{array}{l}\text { Higher scores reflect better } \\
\text { functioning. The self-report item } \\
\text { scores ranges from } 0-1 \text {. } \\
\text { The informant-report measure } \\
\text { item scores ranges from } 0-4 \text {. }\end{array}$ \\
\hline UPSA & Performance & $\begin{array}{l}\text { Measures levels of capability of performing } \\
\text { specific functional living skills via role play } \\
\text { scenarios. It assesses five domains of functioning } \\
\text { household chores, communication, finance, } \\
\text { transportation, and planning recreational activities. }\end{array}$ & $\begin{array}{l}\text { Higher scores reflect better } \\
\text { functioning. Total score out of } \\
100 \text { (each subscale out of } 20) \text {. }\end{array}$ \\
\hline SSPA & Performance & $\begin{array}{l}\text { Role-play test assessing communication skills of } \\
\text { people with serious mental illness Participants } \\
\text { receive of two scenarios, followed by a } 3 \text { minute } \\
\text { role play for each. The SSPA has also been } \\
\text { adapted for use in a medical and which includes } \\
\text { two further role plays, specific to this setting }\end{array}$ & $\begin{array}{l}\text { Higher scores reflect better } \\
\text { functioning. Rated on } 5 \text {-point } \\
\text { Likert scales of social } \\
\text { appropriateness, ranging from } 1 \\
\text { (low) to } 5 \text { (high). }\end{array}$ \\
\hline SBS & Observational & $\begin{array}{l}\text { Designed for completion by inpatient staff. } \\
\text { Measures the severity of problematic behaviours, } \\
\text { such as social avoidance, appropriateness of } \\
\text { interactions, and manners }\end{array}$ & $\begin{array}{l}\text { Higher scores reflect worse } \\
\text { functioning. Scores range from } \\
30 \text { to } 115 \text {, with Rated from } 1-5 \text {. }\end{array}$ \\
\hline MCAS & Informant rated & $\begin{array}{l}\text { Measure of community functioning. It contains } 17 \\
\text { items for four domains; interference with } \\
\text { functioning, adjustment to living, social } \\
\text { competence and behavioural problems. }\end{array}$ & $\begin{array}{l}\text { Higher scores reflect better } \\
\text { functioning. }\end{array}$ \\
\hline
\end{tabular}


Table 4. EPHPP Quality Assessment Ratings

\begin{tabular}{|c|c|c|c|c|c|c|c|}
\hline Author & Selection bias & Design & Confounders & Blinding & Measures & Retention & Global rating \\
\hline Bartels et al. 2004 & $\mathbf{M}$ & $\mathbf{S}$ & $\mathbf{S}$ & $\mathbf{W}$ & $\mathbf{S}$ & $\mathbf{S}$ & Moderate \\
\hline Mueser et al. 2010 & $\mathbf{W}$ & $\mathbf{S}$ & $\mathbf{S}$ & M & $\mathbf{S}$ & M & Moderate \\
\hline Bartels et al. 2014 & $\mathbf{W}$ & $\mathbf{S}$ & $\mathbf{S}$ & $\mathbf{M}$ & $\mathbf{S}$ & M & Moderate \\
\hline Bartels et al. 2013 & $\mathbf{W}$ & M & N/A & $\mathbf{W}$ & $\mathbf{S}$ & M & Weak \\
\hline Bartels et al. 2014 & W & $\mathbf{S}$ & $\mathbf{S}$ & $\mathbf{M}$ & $\mathbf{S}$ & $\mathbf{M}$ & Moderate \\
\hline Pratt et al. 2017 & $\mathbf{W}$ & M & N/A & $\mathbf{W}$ & $\mathbf{S}$ & $\mathbf{M}$ & Weak \\
\hline Patterson et al. 2003 & $\mathbf{M}$ & $\mathbf{S}$ & $\mathbf{S}$ & $\mathbf{M}$ & $\mathbf{S}$ & $\mathbf{S}$ & Strong \\
\hline Patterson et al. 2006 & $\mathbf{M}$ & $\mathbf{S}$ & $\mathbf{S}$ & $\mathbf{M}$ & $\mathbf{S}$ & $\mathbf{S}$ & Strong \\
\hline Patterson et al. 2005 & $\mathbf{M}$ & $\mathbf{S}$ & $\mathbf{W}$ & M & $\mathbf{S}$ & $\mathbf{S}$ & Moderate \\
\hline Granholm et al. 2005 & $\mathbf{M}$ & $\mathbf{S}$ & $\mathbf{S}$ & M & $\mathbf{S}$ & M & Strong \\
\hline Granholm et al. 2007 & $\mathbf{M}$ & $\mathbf{S}$ & $\mathbf{S}$ & $\mathbf{M}$ & $\mathbf{S}$ & $\mathbf{S}$ & Strong \\
\hline Granholm et al. 2013 & W & $\mathbf{S}$ & $\mathbf{S}$ & M & $\mathbf{S}$ & $\mathbf{M}$ & Moderate \\
\hline Berry et al. 2014 & $\mathbf{M}$ & M & N/A & W & $\mathbf{S}$ & $\mathbf{M}$ & Moderate \\
\hline Schindler 2008 & $\mathbf{S}$ & $\mathbf{M}$ & N/A & W & $\mathbf{S}$ & $\mathbf{M}$ & Moderate \\
\hline Golas et al. 2015 & M & $\mathbf{M}$ & N/A & $\mathbf{W}$ & $\mathbf{S}$ & M & Moderate \\
\hline Gammonley 2006 & $\mathbf{W}$ & $\mathbf{N}$ & $\mathbf{S}$ & $\mathbf{W}$ & $\mathbf{S}$ & $\mathbf{S}$ & Weak \\
\hline Barak et al. 2001 & $\mathbf{M}$ & $\mathbf{S}$ & $\mathbf{W}$ & $\mathbf{M}$ & $\mathbf{S}$ & $\mathbf{S}$ & Moderate \\
\hline
\end{tabular}

Note: $W$, weak; $M$, moderate, S strong; n/a, not applicable for study design. Each domain was rated either 'weak', 'moderate', or 'strong'. Papers were assigned on overall rating of 'strong' (no 'weak' domain ratings), 'moderate' (one 'weak' domain rating) or 'weak' (more than one 'weak' domain rating). 